\title{
ANTAGONISTIC ACTINOBACTERIAL DIVERSITY OF MARINE SEDIMENTS COLLECTED FROM COASTAL TAMIL NADU
}

\author{
MANIKANDAN MADHESLU' ${ }^{1}$, SWAPNA MANI², DURAIMURUGAN KASIVISWANATHAN ${ }^{3}$, \\ SOLAI RAMATCHANDIRANE PRABAGARAN**
}

\begin{abstract}
${ }^{1}$ Department of Biotechnology, Sri Krishna Arts and Science College, Coimbatore, Tamil Nadu, India. ${ }^{2}$ Department of Biotechnology, Mercy College, Palakkad, Kerala, India. ${ }^{3}$ Department of Food Processing and Nutrition Science, School of Community Science and Technology, Indian Institute of Engineering Science and Technology, Shibpur, West Bengal, India. ${ }^{4}$ Department of Biotechnology, Bharathiar University, Coimbatore, Tamil Nadu, India. Email: prabagaran@buc.edu.in
\end{abstract}

Received: 10 September 2018, Revised and Accepted: 17 October 2018

ABSTRACT

Objective: The main objective of the current investigation is to identify the antagonistic potential of marine sediment actinobacterial population collected from coastal regions of Tamil Nadu and Kerala.

Methods: A total of 60 marine sediment samples were collected from 27 locations of coastal Tamil Nadu and Kerala. A total of 85 morphologically distinct actinobacterial strains were isolated and taxonomically characterized. The strains were screened for its antagonistic potential against selected bacteria strains, and the obtained results were statistically analyzed. Further, the strains excelled in producing antimicrobial substances were subjected to electron microscopic and chemotaxonomic studies to get more taxonomic details.

Results: The isolates were identified as different species of Streptomyces, Micromonospora, Saccharopolyspora, Actinopolyspora, Nocardia, Nocardioides, Kitasatospora, and the rest of them were categorized as "unidentified." All the isolates were subjected to antimicrobial assay through cross-streak and well diffusion methods that endorsed 34 (40\%) of them to be active against clinical and reference bacterial strains such as Staphylococcus aureus MTCC 3160, S. aureus (methicillin-resistant), Bacillus pumilus NCIM 2327, Escherichia coli MTCC 1698, E. coli, Shigella flexneri MTCC 1457, and Proteus vulgaris. The predominance of Streptomyces (18) was ascertained and followed by Saccharopolyspora (7), Micromonospora (5), Nocardia (2), and Kitasatospora (2) with considerable antimicrobial activities. Statistical analysis revealed that the isolates BDK01, BMT01, BPY03, and BRS07 showed significant antimicrobial activities. Phenotypic and chemotaxonomic analysis revealed that all four isolates are belonging under Streptomyces genus.

Conclusion: The output of the present investigation revealed that the Streptomyces species are predominant in marine sediments and gain more attention for their antagonistic potential. Therefore, assessment and evaluation of marine microbial diversity were done, which could serve as a potential source for novel antibiotics.

Keywords: Antagonistic potential, Intertidal and sub-littoral zone, Marine actinobacteria, Marine sediment, Tamil Nadu coast.

(C) 2019 The Authors. Published by Innovare Academic Sciences Pvt Ltd. This is an open access article under the CC BY license (http://creativecommons. org/licenses/by/4. 0/) DOI: http://dx.doi.org/10.22159/ajpcr.2019.v12i1.29660

\section{INTRODUCTION}

Marine ecosystem occupies a larger part of the Earth containing different physiochemical and biological features, particularly, the salinity, which makes it different from the terrestrial condition. Discovery of new microbial taxa from the marine environment is a novel approach to discover new metabolites from such regimes. The marine environment facilitates actinobacteria to adapt extreme conditions such as high atmospheric pressure, temperature $\left(0^{\circ} \mathrm{C}-100^{\circ} \mathrm{C}\right)$, and high acidic conditions. It is often reflected in the genetic and metabolic diversity of marine actinobacteria [1], which makes the marine-derived compounds special for medical investigation and industrial applications.

Out of 53 known bacterial phyla, only five were reported for antimicrobial activities [2]. Among them, five bacteria are belonging to the order Actinomycetales account for approximately 7000 bioactive compounds, as reported in the Dictionary of Natural Products. However, only 140 genera of actinobacteria are well described for synthesizing a vast variety of natural products. It is, therefore, vital to isolate novel strains for synthesizing new compounds [3]. Actinobacteria, in the marine environment, are largely unexplored, indigenous population that remains elusive in marine water and sand. This may be due to the lack of concrete effort and a high-profile investigation for the complete understanding. Sometimes terrestrial waterbodies carry actinobacterial spores into the marine habitats, leading to later identification [4].
The Indian subcontinent is covered by two major seas and an ocean with a coastal region of about $7500 \mathrm{~km}$ with an area of 2.02 million sq. $\mathrm{km}$ in our exclusive economic zone, besides an additional stretch of $2000 \mathrm{~km}$ from Andaman-Nicobar and Lakshadweep islands chains. It consists of sandy beaches, rocky shores, cliffs, and mudflats or marshy shores. Tamil Nadu coastal region is almost occupied by the Bay of Bengal for the entire length, and a bit is covered by the Indian Ocean. This region comprises diverse marine habitats such as sea-shore, hypersaline lakes, estuaries, saltpans, and a variety of soil habitats. Microbial diversity and its applications along coastal regions of India were well studied by various investigators in the past decade [5-9]. In the present study, an attempt was made to explore antagonistically potential actinobacterial diversity from the marine sediment samples collected from the coastal Tamil Nadu.

\section{METHODS}

Study area

Sampling was conducted at the Bay of Bengal with fair coverage along the east coast of Tamil Nadu, India (Fig. 1). The sampling area included various ecological niches such as estuaries, brackish water lagoons, and mangrove forest, which varied in physiochemical and biological constituents. In addition to these, tsunami, in 2004, moved some deep sea organism to the coastal regions, which adds merit to our study [10]. Most of the samples were collected in the east coast and two (Calicut and Muttom) were collected from the west coast. 
Collection of marine sediment samples

During the months of April-May in 2012 and 2013, 60 sediment samples were collected from 27 different locations (Table 1). At cruise program, five marine sediment soil samples were collected using the facilities available at Center for Advanced Studies (CAS), Marine Biology, Annamalai University (Parangipettai, Tamil Nadu, India). Other samples were accumulated from intertidal and sub-littoral zones using corer in depth from 10 to $30 \mathrm{~cm}$ and transferred to sterile polythene bag. Samples were transferred to the laboratory as early as possible and stored in a cold room at $4^{\circ} \mathrm{C}$ for future use.

\section{Sample processing and isolation of actinobacteria}

To facilitate actinobacterial isolation, the samples were air-dried and then kept in the hot air oven under $55^{\circ} \mathrm{C}$ for 30 min to eliminate other vegetative bacterial flora. $1 \mathrm{~g}$ of dried marine sediment sample was serially diluted up to $10^{-6}$ in $0.5 \%$ saline before plating on media [11]. The starch casein agar (HiMedia) and Actinomycete isolation agar (HiMedia) were prepared in filtered marine water and autoclaved at $121^{\circ} \mathrm{C}$ in $15 \mathrm{lbs}$ for $15 \mathrm{~min}$. The filter sterilized antibiotics cycloheximide (HiMedia) $(50 \mu \mathrm{g} / \mathrm{ml})$ and nalidixic acid (HiMedia) $(50 \mu \mathrm{g} / \mathrm{ml})$ were incorporated into the sterile media at approximately $55^{\circ} \mathrm{C}[12]$. The serially diluted samples were seeded on appropriate plates and incubated at room temperature for 10-12 days. At the end of the incubation period, all plates were observed for the complete growth of actinobacterial colonies and were selected for further studies. The fully grown actinobacteria are characterized by tough leathery colonies having well-developed, branched vegetative, and aerial mycelia with spores [13]. They were selected based on the location, colony size, morphology, and color of the aerial and substrate mycelia. A total of 85 isolates were sub-cultured on yeast extract malt extract agar medium (ISP2), and pure cultures were prepared as $20 \%$ glycerol stock and stored under $-20^{\circ} \mathrm{C}[14]$.

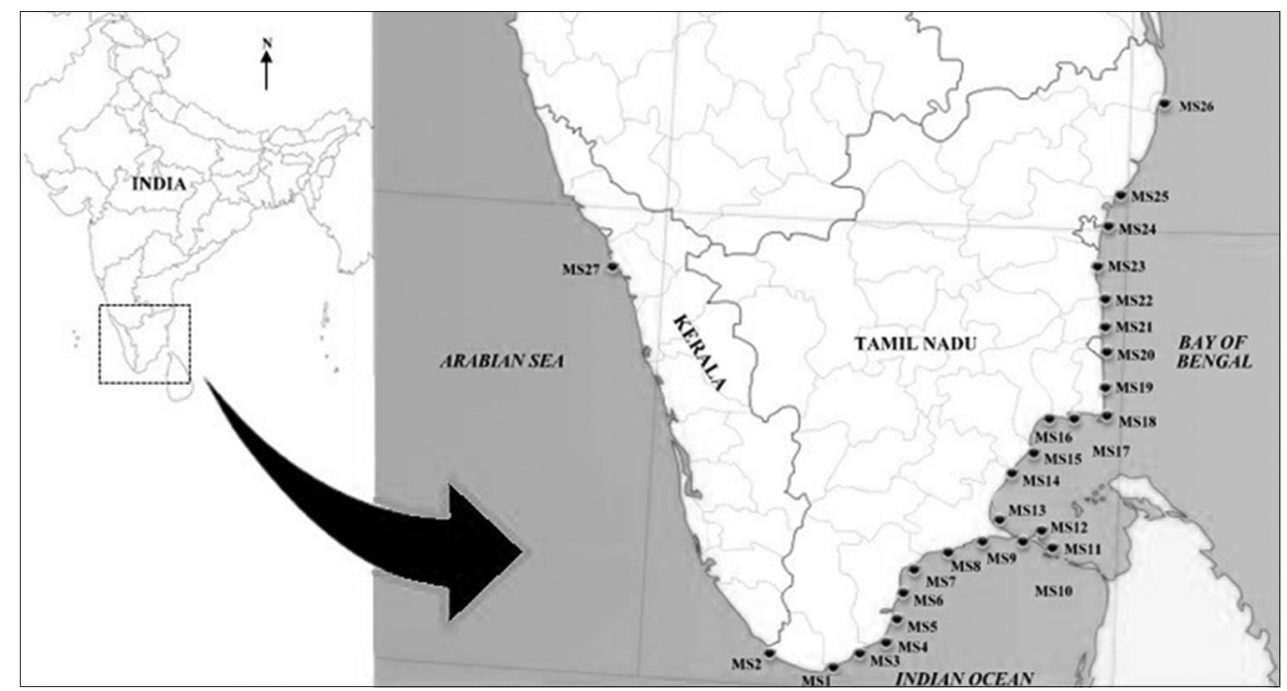

Fig. 1: Schematic representation of map showing sampling area in the Coastal Tamil Nadu and Kerala

Table 1: Details of marine sediment samples collected from different geographical regions of coastal Tamil Nadu and Kerala

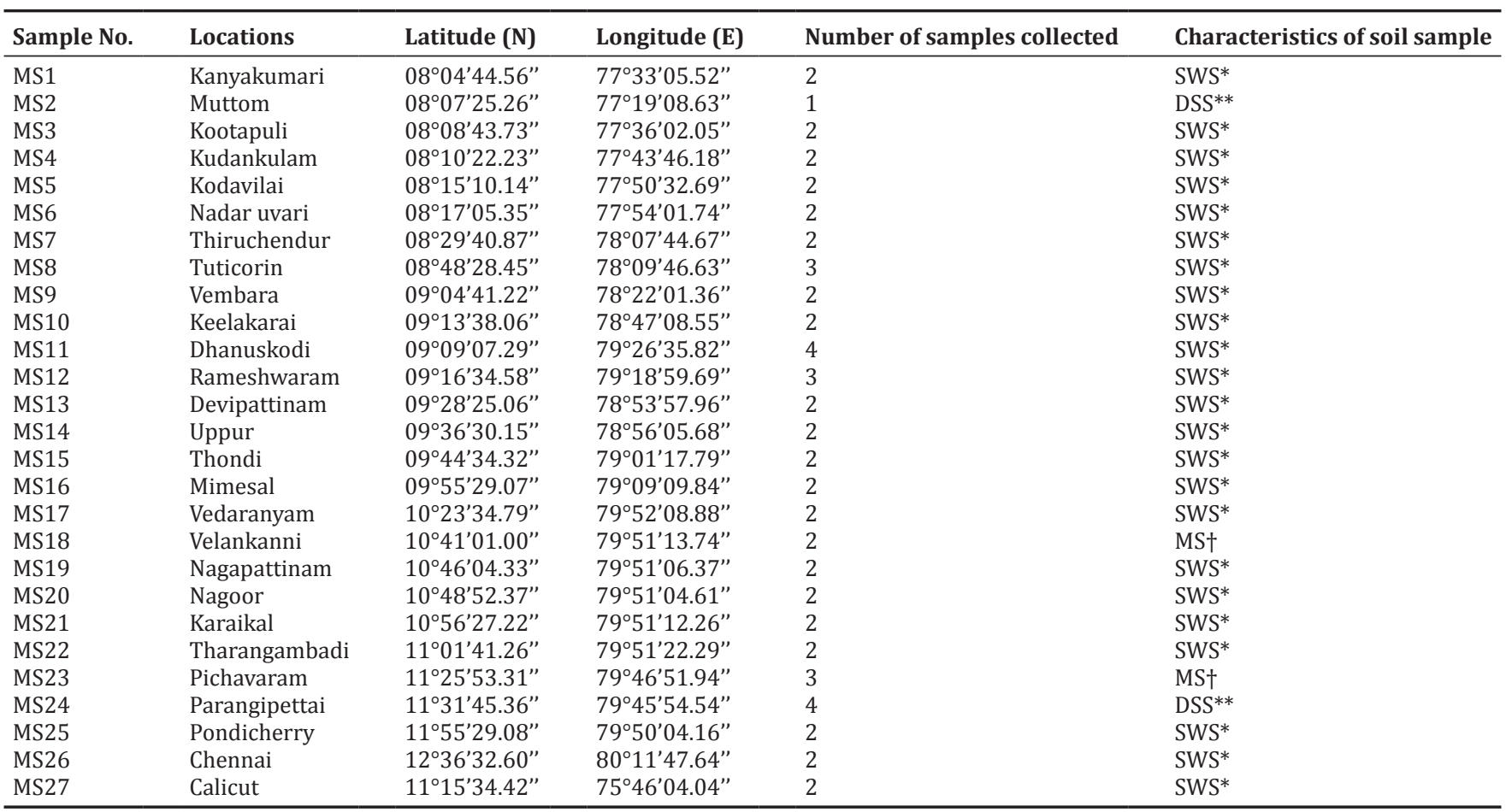

SWS $=$ Shallow water sediment, DSS**=Deep sea sediment, $\mathrm{MS}^{\dagger}=$ Mangrove sediment 
Preliminary identification of isolated actinobacteria

All the isolates were identified based on colony morphology, spore chain arrangement, and biochemical characterization according to Shirling and Gottlieb [15] and Bergey's Manual of Systematic Bacteriology [16]. The color of the mycelia was visually perceived, and all the isolates were made as a thin film on glass slide, heat fixed, and subjected to Gram staining and acid-fast staining. Microscopic coverslip was placed at an angle of the growing actinobacterial colonies in an agar plate. After observing good mycelial propagation on the coverslip, it was removed and placed on a glass slide for detailed observation of spore morphology, spore-bearing hyphae, structure and arrangement of the spore chain on the substrate, and aerial mycelium by light microscopy at $\times 1500$ magnification (Olympus, India).

Screening for antimicrobial compound producing actinobacteria To identify the antimicrobial effectiveness of the isolates, reference and clinically derived bacterial cultures were collected from Institute of Microbial Technology, Chandigarh, India, and Kovai Medical Center and Hospital, Coimbatore, India. The bacterial cultures such as Streptomyces griseus subsp. Griseus MTCC 4734, Staphylococcus aureus MTCC 3160, Bacillus pumilus NCIM 2327, S. aureus (methicillin-resistant), Escherichia coli MTCC 1698, E. coli (ESBL), Shigella flexneri MTCC 1457, Proteus vulgaris, and Enterobacter cloacae were availed from the above said sources. S. griseus subsp. griseus MTCC 4734 was used as positive control for the entire study.

The agar plug method was performed for all the isolates to identify the antimicrobial compound-producing actinobacteria [17]. The purified actinobacteria were streaked on ISP2 media and incubated for 7 days at $28 \pm 2^{\circ} \mathrm{C}$. After observing good growth, the listed test bacterial strains were swabbed on the nutrient agar and a small well sized about $5 \mathrm{~mm}$ in diameter were made with a sterile corer. Later, the empty nutrient agar wells were replaced with similar sized agar plug from the ISP2 and incubated at $37^{\circ} \mathrm{C}$. The inhibition zone was measured after 24 and $48 \mathrm{~h}$. Based on the presence of inhibition zone, the antimicrobial compoundsproducing actinobacteria were selected. The isolates excelled in agar plug assay were inoculated into $250 \mathrm{~mL}$ conical flask containing starch-casein broth (75 mL/flask) and incubated in an orbital shaker at $180 \mathrm{rpm}$ under $26^{\circ} \mathrm{C}-28^{\circ} \mathrm{C}$ for $7-8$ days. After growth, the fermented broth was harvested by centrifugation at $6000 \mathrm{rpm}$ for $10 \mathrm{~min}$, and the collected supernatant was challenged against the previously mentioned pathogenic bacteria as suggested by Parthasarathi et al. [18]. Concurrently, a positive control S. griseus MTCC 4734 was subjected for all the above-mentioned analysis.

\section{Statistical analysis of antagonistic efficacy of isolates}

The statistical analysis (SPSS 16.0) was performed to compare the antagonistic efficacy of the isolates. The well diffusion results of all 34 isolates against test bacteria were taken into account, and the difference among the antimicrobial efficacy of every individual isolates was analyzed by post hoc (Turkey's test).

\section{Characterization of antagonistic significant isolates}

The selected antagonistically significant isolates were subjected to electron microscopic and chemotaxonomic characterization. Coverslip culture technique was adopted for light microscopic studies. Actinobacterial culture plate was prepared, and sterile coverslips were placed at an angle of $45^{\circ}$. After the appropriate growth, the coverslips were used for scanning electron microscopic observation. For cell wall sugar, samples were prepared and investigated by the prescribed methods of Suput et al. [19]. Cell wall amino acids were extracted using the standard protocol [20] and analyzed using reverse phase high-performance liquid chromatography (HPLC) [21] to validate the presence of LL-2,6-Diaminopimelic acid. For cellular fatty acid analysis, the samples were prepared by the method of Sasser [22], and methylated fatty acids were analyzed through GC-MS (Model - THERMO GC - TRACE ULTRA VER: 5.0, MS DSQ).

\section{RESULTS}

In this study, 60 marine sediment samples were collected from 27 locations of coastal Tamil Nadu and selected parts of Kerala (Fig. 1). All the samples were collected during the months of April-May 2012 and 2013 to avoid the influence of the rainy season. Color of the sediment samples varied from black to brown in nature. Sediment textures were found to be clayey, sandy, and with small pebble-like structures. Besides, the samples from mangrove sediment were light-brown to dark brown and sticky like fine mud. The $\mathrm{pH}$ of the collected sediment samples varied from 7.2 to 8.4.

The actinobacterial populations were investigated from sediment samples through spread plate using two media, namely starch casein agar and actinomycetes isolation agar prepared in the sea water. On both the media, colonies with well-developed, tough leathery, mycelia, sometime pigmented, and sporulating, often observed to differ in shape, color, and size [13]. Likewise, 85 morphologically distinct actinobacterial strains were isolated from both the media. Isolation of similar colonies from same samples was avoided to evade the re-isolation of the same strain. Among them, 57 colonies were isolated on starch casein agar, whereas the rest 28 colonies were isolated from actinomycete isolation agar. Nearly $88.23 \%$ of the actinobacterial strains were isolated from marine shallow-water sediment, 9.41\% from mangrove sediment, and 2.35\% from deep-sea sediment. Reason for such results could be excessive number of samples, of which 50 samples are from shallow water sediment. The mangrove sediment yielded a high proportion of the actinobacterial population, whereas deep-sea sediment yielded significantly less. The samples collected from Rameshwaram (MS12) (7 colonies), Pichavaram (MS23) (7 colonies), and Dhanushkodi (MS11) yielded considerable number of diverse colonies in terms of morphology. While low population density was recorded in four places such as Nadavavurai (MS06), Vembara (MS09), Velankanni (MS18), and Tharangambadi (MS22), only one kind of morphologically alike actinobacterial population was seen in both Uppur (MS14) and Karaikal (MS21).

Majority of the isolates showed powdery morphology, whereas others showed mucoidal and shrunken skin-like appearance. Colony morphology differed in the aspects of form, elevation, and margin of the colony. Most of the colonies were circular, whereas a few were filamentous and irregular. The colonies were uniquely elevated as convex, raised, pulvinate, and umbonate. Margin of the colonies was different such as entire, undulate, erose, and filamentous. Moreover, a moderate number of colonies had multiple layers of the concentric circle. Predominant colonies were white and related colors, though others include pink, red, yellow, brown, blue, and black.

All the isolates were subjected to staining and microscopic examination. Gram staining revealed that all the 85 isolates were Gram-positive. Acidfast staining results showed that many of them $(84.7 \%)$ were non-acid fast and the remaining were weakly acid fast (15.3\%). Considering the results of colony morphology, pigmentation, color of aerial and substrate mycelia, staining results, spore chain ornamentation, biochemical characterization, and chemotaxonomic characterization, of 85 isolates, $40 \%$ were identified as Streptomyces, $18 \%$ as Micromonospora, 14\% as Saccharopolyspora, $7 \%$ as Actinopolyspora, 8\% as Nocardia, 2\% as Nocardioides, $6 \%$ as Kitasatospora, and 5\% remained as unidentified (Fig. 2).

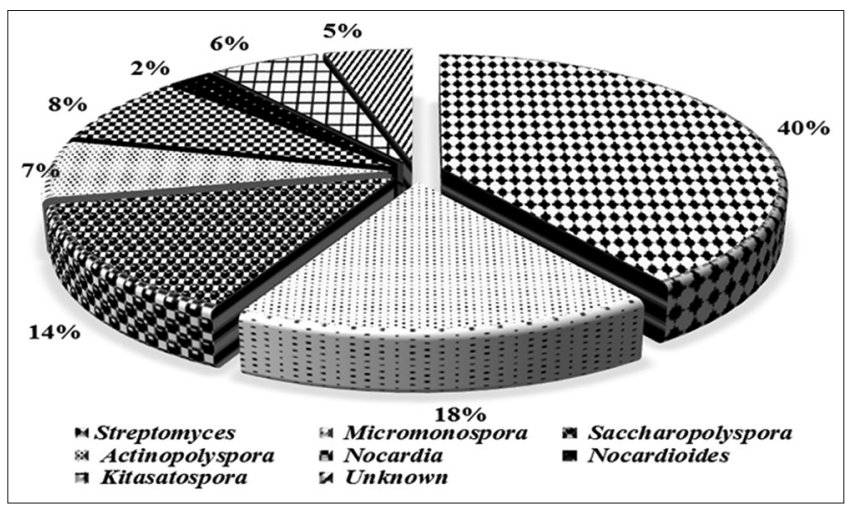

Fig. 2: Distribution of actinobacterial populations in marine sediments 
In the present investigation, the actinobacteria made of entire samples have both antagonistic and non-antagonistic abilities. Among them, 85 actinobacterial isolates challenged against various clinical and reference bacterial strains by agar plug assay, and 34 (40\%) isolates showed considerable antagonistic activity. Pichavaram, Dhanushkodi, and Mimesal excelled in antagonistic activity with $>3$ isolates in each sample. Rest of the samples had between one to two potent actinobacterial colonies, whereas the samples from Kanyakumari, Nadar uvari, Vembara, Velankanni, and Karaikal did not yield any single potent isolate (Fig. 3). Of 34 potential isolates, 18 (53\%) were Streptomyces. Moreover, the other genera such as seven of Saccharopolyspora (20\%), five of Micromonospora (15\%), two of Nocardia (6\%), and two of Kitasatospora (6\%) are reported in the current study for their antagonistic ability.

Among the potential isolates, $35 \%$ of the isolates were active against Gram-positive clinical and reference bacterial strains, and $18 \%$ of the isolates had activity against Gram-negative, whereas $47 \%$ had broadspectrum activity against both Gram-positive and Gram-negative bacteria. Overall, $58.8 \%$ of the potential isolates had good antagonistic activity against $B$. pumilus NCIM 2327 . In addition, $50 \%$ of the potential antagonistic isolates were very active against $S$. aureus MTCC 3160 and E. coli MTCC 1698. Similarly, 29.4\% of the isolates were active against $S$. aureus (methicillin-resistant) and E. coli (ESBL). Moreover, 26.4\% and $20.5 \%$ of the isolates were capable of producing antimicrobial compounds against S. flexneri MTCC 1457 and P. vulgaris, respectively. The obtained results of well diffusion assay were qualitatively almost similar as agar plug assay but quantitatively differed (Table 2). On the basis of mean average, all the isolates were categorized into five components through the statistical analysis method. It is identified that the fifth component, which includes BDK01, BMT01, BPY03, and BRS07, exhibited high antimicrobial ability. Furthermore, the isolate BDK01 excelled in antimicrobial ability as indicated by its mean performance.

The cultural morphology and biochemical characterization of all the four selected isolates were tested on different media, and the results were tabulated (Table 3).

In electron microscopic study, BDK01 and BPY03 showed rectiflexibiles sporophore morphology, and BMT01 belonged to retinaculiaperti. Isolate BRS07 exhibited spiral spore chain morphology (Fig. 4).

Chemotaxonomic characterization of BDK01, BMT01, BPY03, and BRS07 revealed that no sugar was present in the cell wall, whereas glycine and LL-2,6 diaminopimelic acid were present. The chromatogram obtained for standard amino acid revealed that compound will get eluted at $3.44 \mathrm{~min}$ from the column.

Similarly, the cell wall amino acid isolated from isolates exhibited a similar chromatogram (Fig. 5) at the specific time with minor deviations. The result of the cell wall fatty acid analysis is given in Table 4 .

\section{DISCUSSION}

Actinobacteria are potential sources for many new antibiotics, and specifically, Streptomyces is an important genus among them with a considerable contribution to pharmaceutical industries. Its diverse population and metabolites are promising factors to explore next-generation antibiotics. Some of the recent studies [23,24] highlight the concerns on the inappropriate usage of antibiotics and the development of multiple drug-resistant bacteria. Despite

Table 2: Antibacterial activity of fermented broth by isolates by well diffusion method

\begin{tabular}{|c|c|c|c|c|c|c|c|c|}
\hline \multirow[t]{2}{*}{ Isolate code } & 1 & 2 & 3 & 4 & 5 & 6 & 7 & 8 \\
\hline & \multicolumn{8}{|c|}{ (Zone of inhibition in $\mathrm{mm}$ ) } \\
\hline Control & 14.3 & 9.6 & - & 14.0 & 11.3 & 8.3 & - & - \\
\hline BMT1 & 21.6 & 16.3 & 14.0 & 14.6 & 12.3 & 9.60 & 22.6 & 17.6 \\
\hline BKT1 & - & 7.6 & 8.3 & - & - & - & - & - \\
\hline BKD1 & 14.3 & - & - & - & - & - & - & - \\
\hline BKD2 & - & - & - & 8.6 & - & - & - & - \\
\hline BKV2 & 14.6 & 11.6 & - & 15.6 & - & - & - & - \\
\hline BTC2 & - & - & - & 16.0 & - & 15.6 & 13.6 & \\
\hline BTT1 & - & - & 16.6 & 14.0 & - & 8.3 & - & - \\
\hline BKL1 & - & 11.3 & - & - & - & - & - & - \\
\hline BDK1 & 20.0 & 18.3 & 24.3 & 28.0 & 33.6 & 28.0 & 22.0 & 12.3 \\
\hline BDK3 & 25.6 & 18.0 & - & 20.3 & - & - & - & - \\
\hline BDK6 & 19.6 & - & 16.3 & - & - & - & - & - \\
\hline BRS4 & 10.6 & 8.3 & 8.6 & 6.6 & - & - & - & - \\
\hline BRS7 & 14.3 & 12.3 & 13.6 & 13.6 & 20.0 & 11.3 & 14.0 & 16.0 \\
\hline BDV1 & 9.3 & 7.6 & - & - & 7.3 & - & - & - \\
\hline BUP1 & - & 20.6 & 16.6 & 14.6 & 15.6 & - & 8.6 & - \\
\hline BTD1 & - & - & - & - & 8.3 & - & - & - \\
\hline BMM1 & - & - & - & - & - & 15.6 & 15.3 & - \\
\hline BMM2 & - & 9.6 & - & - & - & - & - & - \\
\hline BMM3 & - & 8.6 & - & 11.3 & - & - & - & - \\
\hline BVR1 & 10.3 & - & - & - & - & - & - & - \\
\hline BVR3 & - & - & - & - & - & 9.6 & - & - \\
\hline BNG4 & - & 15.3 & - & - & - & - & - & - \\
\hline BNG6 & 10.3 & - & - & - & - & - & - & - \\
\hline BNO1 & - & 8.0 & - & - & 10.6 & - & - & - \\
\hline BTR1 & - & 17.6 & - & - & - & - & - & - \\
\hline BPH 1 & 18.6 & - & - & 28.3 & 24.3 & - & - & - \\
\hline BPH 2 & 11.6 & 10.3 & - & 19.3 & 20.3 & - & - & - \\
\hline BPH 5 & - & - & - & 14.3 & - & - & - & - \\
\hline BPH 6 & 18.6 & - & - & 16.6 & - & 22.6 & - & - \\
\hline BPP1 & 17.6 & 16.6 & - & 13.6 & - & - & - & - \\
\hline BPY1 & - & 18.6 & - & - & - & - & - & - \\
\hline BPY3 & 12.6 & 21.6 & 20.0 & 30.3 & 32.3 & 13.6 & 14.6 & 10.6 \\
\hline $\mathrm{BCH} 1$ & 14.3 & - & 14.6 & - & - & - & - & - \\
\hline BCC 3 & - & 9.6 & - & - & - & - & - & - \\
\hline
\end{tabular}

Control Streptomyces griseus subsp. griseus MTCC 4734; 1 . Staphylococcus aureus MTCC 3160; 2. Bacillus pumilis NCIM 2327; 3. Staphylococcus aureus (methicillin resistant); 4. Escherichia coli MTCC 1698; 5. Escherichia coli (ESBL); 6. Shigella flexneri MTCC 1457; 7. Proteus vulgaris; 8. Enterobacter cloacae; mm, millimeter; - No activity

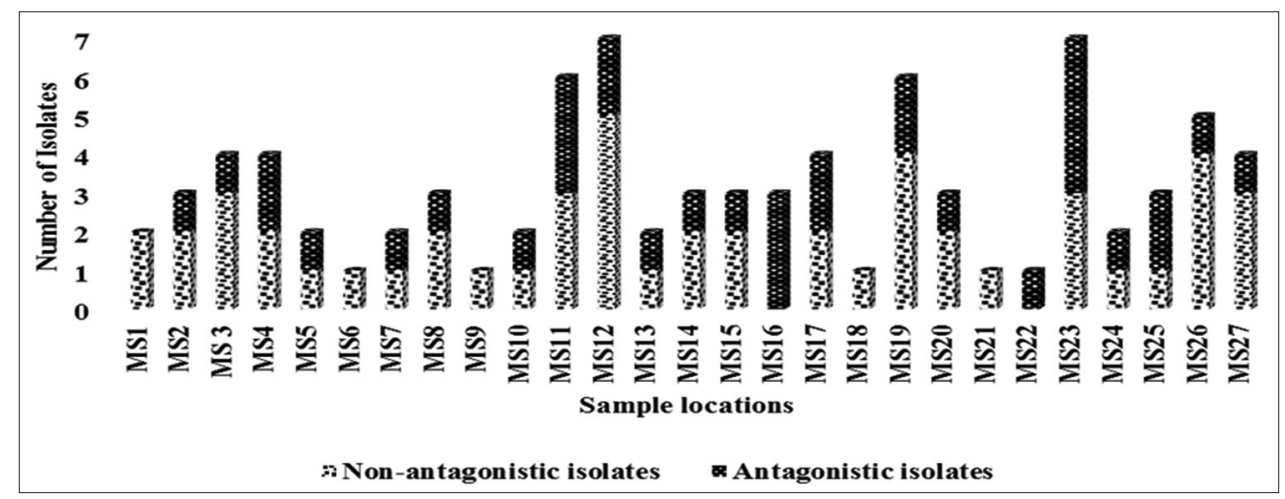

Fig. 3: Comparison of non-antagonistic and antagonistic isolates from different locations 
Table 3: Phenotypic characterization of the isolates BDK01, BPY03, BMT01, and BRS07 on starch casein agar

\begin{tabular}{|c|c|c|c|c|}
\hline Characteristics & BDK01 & BPY03 & BMT01 & BRS07 \\
\hline Colony morphology & $\begin{array}{l}\text { Circular, umbonate, } \\
\text { entire }\end{array}$ & $\begin{array}{l}\text { Circular, umbonate, } \\
\text { entire }\end{array}$ & Circular, flat, curled & $\begin{array}{l}\text { Circular, crateriform, } \\
\text { curled }\end{array}$ \\
\hline Sporophore morphology & $\begin{array}{l}\text { Straight or } \\
\text { rectiflexibiles }\end{array}$ & $\begin{array}{l}\text { Straight or } \\
\text { rectiflexibiles }\end{array}$ & Retinaculiaperti & Spiral \\
\hline Spore surface & Smooth & Smooth & Spiny & Warty \\
\hline Spore chain length & $>30$ spores & $>30$ spores & $>10$ spores & $>30$ spores \\
\hline Spore size & $0.840 \times 0.508 \mu \mathrm{m}$ & $1.036 \times 0.508 \mu \mathrm{m}$ & $1.123 \times 0.5 \mu \mathrm{m}$ & $1.075 \mu \mathrm{m} \times 459.4 \mathrm{~nm}$ \\
\hline $\begin{array}{l}\text { Colour of aerial } \\
\text { mycelium }\end{array}$ & Pale orange & Pale orange & $\begin{array}{l}\text { Gray in middle and white concentric circle } \\
\text { around the colonies }\end{array}$ & $\begin{array}{l}\text { White with white } \\
\text { concentric circle }\end{array}$ \\
\hline $\begin{array}{l}\text { Color of substrate } \\
\text { mycelium }\end{array}$ & Brown & Brown & Dull brown & Dull brown \\
\hline Spore mass & Pale orange & Pale orange & Whitish-gray & Chalky white \\
\hline Pigment & Brown color & Brown color & No pigment & No pigment \\
\hline
\end{tabular}
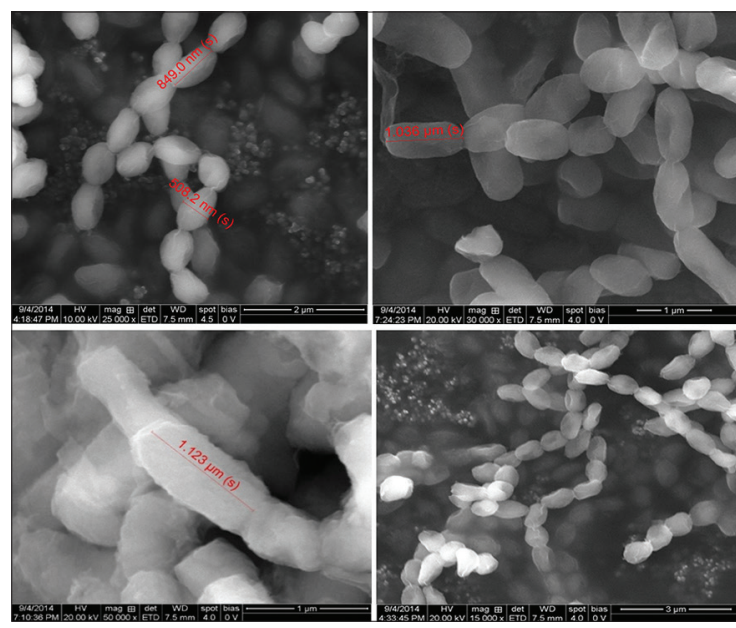

Fig. 4: Electron micrographs of (a) BDK01, (b) BPY03, (c) BMT01, and (d) BRS07

the continuous investigation on marine natural products, there is a large lacuna in the field of medicine for alternate therapeutic agents against most pathogenic microbes and clinical disorders. This prompts researchers to investigate for novel antimicrobials, particularly from actinobacteria. In 2009, Ramesh and Mathivanan also emphasized the importance of discovery of the new antibiotics to challenge plant and animal pathogens. The marine sediment was pondered as a potential source for diverse actinobacterial populations and its biologically active metabolite by many investigators $[7,25,26]$.

Previous studies conducted on microbial population in the South-east coast of India after the 2004 tsunami [27-29] had opened further arena to the quest. When giant tidal waves like tsunami occurred in the sea, it was possible that the deeper nutrient-rich water came up to the surface [30]. This could have influenced the marine environment to a great extent due to nutrient and mineral flux resulting in variation in marine biodiversity in pre- and post-tsunami sediment. Based on these evidences, the marine sediment samples were collected from the East coast with the goal of isolation, identification of potential marine antagonistic actinobacterial population, and characterization of their products. In the present study, the sediment samples of coastal Tamil Nadu and Kerala were collected during pre-monsoon period of 2012 and 2013. Consequently, if samples collected after monsoon, inward freshwater might have affected the isolation of indigenous marine actinobacteria.

The places with good number of actinobacterial populations were identified, and the reason for this population density could be the influence of soil factor. The sediment sample of Pichavaram mangrove was black, sticky fine mud probably with high organic content and elevated levels of carbon and nitrogen sources. Other places such as Rameshwaram and Dhanushkodi also yielded a high number of actinobacteria. Previously, while studying Palk Strait region of Bay of Bengal, Vijayakumar et al. [31] recorded a high number of actinobacteria, particularly, 39 Streptomyces strains. Rest of the sampling sites yielded moderate or less number of actinobacteria, which were taken from the littoral zone, probably with poor organic contents. Culturing the samples in more than one media always increase the probability for isolation of diverse actinobacterial populations. Hence, the recovered bacteria were also influenced by the type of media and the growth conditions employed, which reflects the nutritional contents $[32,33]$. About $81.4 \%$ of the collected marine sediment samples had the genus Streptomyces. Such results highly comply with the previous studies of Mitra et al. [26] and Suthindhiran and Kannabiran [34]. The genus Streptomyces is more predominant in marine environment compared with all other actinobacterial population $[8,35]$. Phenotypically the streptomycetes colonies are elevated, convex, and powdery in nature [36]. The spore morphology of Streptomyces and Micromonospora was compared with the results obtained by Vijayakumar et al. [31]. Since 1970, >3000 species of Streptomyces were reported in various literature and patents [37]. However, only 600 Streptomyces species alone were well defined by most investigators [38].

Micromonospora is the second largest population in the marine environment [39]. Similarly, in this study, $>44.4 \%$ of the marine sediment samples had Micromonospora. Out of 85 total isolates, $18 \%$ of them belonged to the genus Micromonospora followed by Saccharopolyspora (14\%). Small proportions of other rare actinobacterial populations such as Actinopolyspora, Nocardia, Nocardioides, and Kitasatospora were reported $[7,26,40]$. The sporophore morphology of Saccharopolyspora, Actinopolyspora, Nocardia, and Nocardioides was highly similar [41,42]. The morphology of Kitasatospora of the current study is in high agreement with the previous investigation of Gill et al. (2014) [52]. Almost $5 \%$ of the colonies were reported as unidentified due to unstable growth and irregular spore chain arrangement. Numerous isolated genera of actinobacteria as reported in marine water of Bay of Bengal, in his study includes Streptomyces, Actinopolyspora, Kitasatosporia, and Micromonospora. Other potential species that have been reported are Faenia, Ampullariella, Intrasporangium, Sporichthya, Nocardia, and Nocardioides [43].

After preliminary screening by agar plug method, of 85 isolates, $34(40 \%)$ were identified as potential producers of antimicrobial compounds against clinical and reference bacterial strains. Around $82 \%$ of the sediment samples had antagonistic potential, whereas $18 \%$ showed no significant performance. Among seven colonies of Pichavaram mangrove, four were capable of producing antimicrobials. Mangrove sediment is always highly influenced by rich organic content of the soil that can promote the diversity of the microbial population, leading to nutritional competition for survival of every organism to combat a chemical war. Hence, the microbial population which exists in this zone may contain high antagonistic activity [44]. 


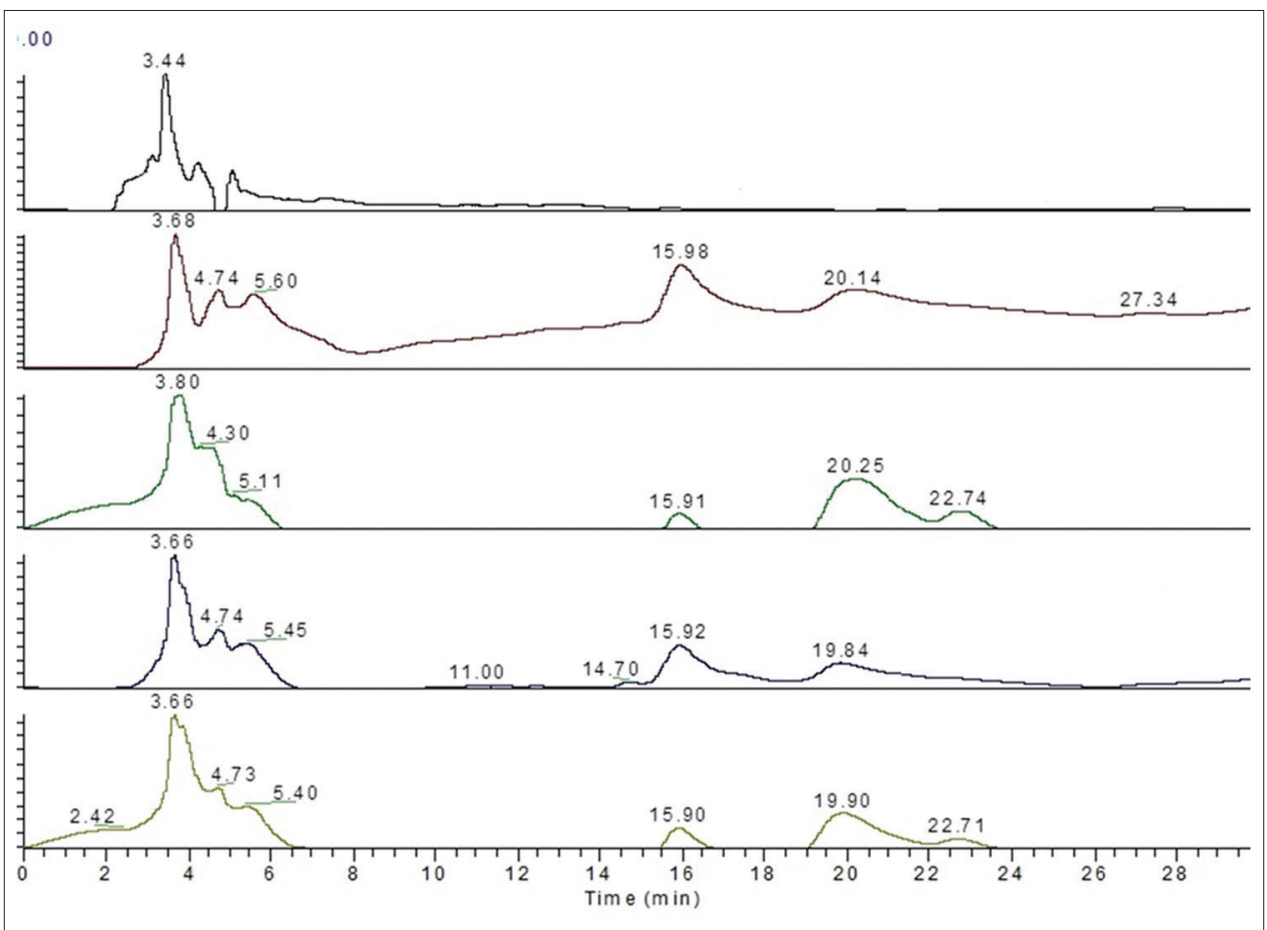

Fig. 5: Cell wall amino acid profile using reverse-phase high-performance liquid chromatography; (a) standard LL-2,6-diaminopimelic acid, (b) BDK01, (c) BPY03, (d) BMT01, and (e) BRS07

Table 4: Taxonomically significant fatty acid methyl esters present in cell wall extract of isolates BDK01, BPY03, BMT01, and BRS07 (fatty acid composition in percentage)

\begin{tabular}{lllll}
\hline Fatty acid & BDK01 & BPY03 & BMT01 & BRS07 \\
\hline $\mathrm{C}_{15: 0}$ anteiso (12-Methyl) & 46.03 & 56.60 & 39.57 & 23.42 \\
$\mathrm{C}_{15: 0}$ & - & 7.10 & - & - \\
$\mathrm{C}_{16: 0}$ & 12.56 & 21.30 & 42.11 & 48.48 \\
$\mathrm{C}_{17: 0}$ anteiso (14-Methyl) & - & 14.99 & - & - \\
$\mathrm{C}_{17: 0}$ & - & - & 18.30 & - \\
$\mathrm{C}_{18: 0}$ w6c $(9 \mathrm{Z}, 12 \mathrm{Z})$ & 41.39 & - & - & 20.08 \\
$\mathrm{C}_{18: 2}$ w6 & - & - & - \\
\hline
\end{tabular}

Similarly, other regions such as Dhanushkodi and Mimesal (Part of Palk Strait of Bay of Bengal) yielded more than 3 antagonistic potential actinobacteria. Earlier, Vijayakumar et al. [8] isolated 66 actinobacterial strains from the Palk Strait region of Bay of Bengal between India and Sri Lanka. About 37\% (25) of them had significant antimicrobial activity against various bacterial and fungal pathogens. Rest of the marine sediment samples screened had at least one antagonistically potential actinobacteria. Overall, $50 \%$ of the isolates had outstanding antagonistic potential against B. pumilus NCIM 2327, S. aureus MTCC 3160, and E. coli MTCC 1698. Therefore, Bay of Bengal is proven to be a pivot of biologically valuable compound producing actinobacterial population. Ramesh and Mathivanan [7] reported the potential actinobacterial populations of Bay of Bengal, which is active against human and plant pathogens. Out of 288 isolates, 53\% (153) of them showed antagonistic activity against human pathogens such as E. coli, Streptococcus epidermis, Pseudomonas aeruginosa, Bacillus subtilis, and Candida albicans. A similar study carried by Nithyanand et al. [45] indicated the antimicrobial ability of actinobacteria isolated from Gulf of Mannar.

In the current study, of 34 potential isolates, $>53 \%$ (18) belong to the genus Streptomyces. Among them, isolates BDK01, BPY03, BRS07, and BMT01 were excelled in antimicrobial efficacy against the test bacterial strains. According to Miyadoh [46], Streptomyces, a potent genus in this group, produce as much as $75 \%$ of the commercially and medically useful antibiotics. It does not mean that non-streptomycetes species are not producing any secondary metabolite. The reason may be lack of proper isolation media and techniques for the isolation of these strains from the environment [47]. Different genera such as Saccharopolyspora, Micromonospora, Nocardia, and Kitasatospora reported in this study still had good antimicrobial activity. Earlier, Saccharopolyspora erythraea has reported for the production of erythromycin-A by Wu et al. [48]. Carlson et al. [49] reported a chemopreventive macrolide antibiotic from a marine-derived Micromonospora sp. Tranvalencin-Z, an antimicrobial compound produced by Nocardia transvalensis IFM 10065, was reported by Mukai et al. [50]. In addition, in the previous study of Tsuda et al. [51], Nocardia brasiliensis was reported for the production of a cytotoxic compound Brasilibactin A. Kitasatospora cystarginea was identified as a potential source for cystargolides (A) 1 and (B) 2, by Gill et al. [52].

The shake flask method is the common tool used by many investigators for checking the antagonistic ability of their isolates [18]. To check the prolonged production ability of the organism, shake flask fermentation was performed for all the isolates, and the results were recorded. The outputs of well diffusion assay were qualitatively similar to the agar plug assay but differed quantitatively against each test pathogen (Table 2). The statistical analysis of the results obtained through one-way ANOVA grouped the isolates into five categories based on the mean average (Table 5). Particularly, the isolates BDK01, BPY03, BRS07, and BMT01 (which were identified as Streptomyces genus) were categorized into separate group with the elevated mean average of the zone of inhibition.

In chemotaxonomic characterization, no sugar was found in all the four selected isolates: BDK01, BPY03, BRS07, and BMT01. Similarly, in cell wall amino acid analysis, glycine and LL 2,6 diaminopimelic acid were found in all the four isolates. Reverse phase HPLC chromatogram shows that the retention of the standard LL-2,6-Diaminopimelic acid is at $3.44 \mathrm{~min}$ and correspondingly the elution of LL-2,6-Diaminopimelic acid from selected isolates exhibited similar retention time with minor variations. This clearly shows that isolates contain LL-2,6-Diaminopimelic acid in their cell wall. These results were high agreement with the study of Phongsopitanun et al. (2014) [53]. Hence, it is confirmed that the cell wall of all the isolates belonged to Type I, according to Suput et al. Fatty 
Table 5: Statistical analysis of antimicrobial ability of actinobacterial populations by post hoc (Turkey's test)

\begin{tabular}{|c|c|c|c|c|c|c|}
\hline \multicolumn{7}{|c|}{ Tukey test } \\
\hline \multirow[t]{2}{*}{ Group } & \multirow[t]{2}{*}{$\mathbf{n}$} & \multicolumn{5}{|c|}{ Subset for alpha=0.05 } \\
\hline & & 1 & 2 & 3 & 4 & 5 \\
\hline BTD1 & 8 & 1.0375 & & & & \\
\hline BKD2 & 8 & 1.0750 & & & & \\
\hline BMM2 & 8 & 1.2000 & & & & \\
\hline BVR3 & 8 & 1.2000 & & & & \\
\hline BCC3 & 8 & 1.2000 & & & & \\
\hline BVR1 & 8 & 1.2875 & & & & \\
\hline BNG6 & 8 & 1.2875 & & & & \\
\hline BKL1 & 8 & 1.4125 & & & & \\
\hline BKD1 & 8 & 1.7875 & 1.7875 & & & \\
\hline BPH 5 & 8 & 1.7875 & 1.7875 & & & \\
\hline BNG4 & 8 & 1.9125 & 1.9125 & & & \\
\hline BKT1 & 8 & 1.9875 & 1.9875 & & & \\
\hline BTR1 & 8 & 2.2000 & 2.2000 & & & \\
\hline BNO1 & 8 & 2.3250 & 2.3250 & & & \\
\hline BPY1 & 8 & 2.3250 & 2.3250 & & & \\
\hline BMM3 & 8 & 2.4875 & 2.4875 & & & \\
\hline BDV1 & 8 & 3.0250 & 3.0250 & & & \\
\hline $\mathrm{BCH} 2$ & 8 & 3.6125 & 3.6125 & 3.6125 & & \\
\hline BMM1 & 8 & 3.8625 & 3.8625 & 3.8625 & & \\
\hline BDK6 & 8 & 4.4875 & 4.4875 & 4.4875 & & \\
\hline BTT1 & 8 & 4.8625 & 4.8625 & 4.8625 & & \\
\hline BKV2 & 8 & 5.2250 & 5.2250 & 5.2250 & & \\
\hline BRS4 & 8 & 5.5125 & 5.5125 & 5.5125 & & \\
\hline BTC2 & 8 & 5.6500 & 5.6500 & 5.6500 & & \\
\hline BPP1 & 8 & 5.9750 & 5.9750 & 5.9750 & & \\
\hline BPH 6 & 8 & 7.2250 & 7.2250 & 7.2250 & 7.2250 & \\
\hline ВРН 2 & 8 & 7.6875 & 7.6875 & 7.6875 & 7.6875 & \\
\hline BDK3 & 8 & 7.9875 & 7.9875 & 7.9875 & 7.9875 & \\
\hline BPH 1 & 8 & 8.9000 & 8.9000 & 8.9000 & 8.9000 & \\
\hline BUP1 & 8 & 9.5000 & 9.5000 & 9.5000 & 9.5000 & \\
\hline BRS7 & 8 & & 14.3875 & 14.3875 & 14.3875 & 14.3875 \\
\hline BMT1 & 8 & & & 16.0750 & 16.0750 & 16.0750 \\
\hline BPY3 & 8 & & & & 19.4500 & 19.4500 \\
\hline BDK1 & 8 & & & & & 23.3125 \\
\hline Sig. & & 0.768 & 0.050 & 0.058 & 0.072 & 0.663 \\
\hline
\end{tabular}

*Means for groups in homogeneous subsets are displayed

acid methyl ester analysis revealed the presence of several straight and branched chain fatty acids including $\mathrm{C}_{15: 0}$ anteiso (12-Methyl), $\mathrm{C}_{15: 0^{\prime}}, \mathrm{C}_{16: 0^{\prime}}$, $\mathrm{C}_{17: 0^{\prime}}$, and $\mathrm{C}_{17: 0}$ anteiso (14-Methyl), $\mathrm{C}_{18: 0}$, and $\mathrm{C}_{18: 2}$ w6c $(9 \mathrm{Z}, 12 \mathrm{Z})$ in the potential isolates. All these findings suggested that the selected isolates could belong to the genus Streptomyces. To identify the species, all the four strains should be subjected to $16 \mathrm{~S}$ rRNA gene sequencing.

According to Bérdy [54], 75\% of the commercially important antibiotics produced are by Streptomyces, and $25 \%$ of them were produced by rare actinobacteria. The rare actinobacterial species produces chemically diverse, unique, unprecedented, and biologically potent compound with low toxicity [54,55]. Particularly, Micromonospora, Nocardia, and Saccharopolyspora play a very important role in the production of antimicrobial compounds and antibiotics $[1,54,56]$

More than $99 \%$ of the known valuable antimicrobial compounds in the market are derived from the terrestrial actinobacterial compounds. Recently, the efforts decreased gradually due to the distrust that this resource has been exhaustively studied. Hence, the present investigation was done on the marine environment for novel compounds to combat the developing pathogens. Marine actinobacteria were well known for its bioactivities, such as antimicrobial and cytotoxic activities. Particularly, marine Streptomyces are widely distributed in biological sources such as fishes, molluscs, sponges, seaweeds, algae, and mangroves beside seawater sediments [57]. It is gaining importance not only for its taxonomic and ecological perspectives but also for their production of novel bioactive compounds such as antibiotics, enzymes, enzyme inhibitors, pigments, and for its biotechnological applications such as the production of probiotics and single cell proteins. In proving the above statement, research has explored a total of 205 actinomycetes species notably producing industrially important enzymes such as amylase, protease, lipase, esterase, and gelatinase [58]. Furthermore, a recent study at coromandel coastal region of southern India has explored effective marine actinomycete belonging to the species Micropolyspora producing antimycobacterial compounds with potent activity against Mycobacterium tuberculosis [59].

Vested with an enormous wealth of biodiversity in the Bay of Bengal, this study on bioprospecting gains more importance. Marine sediment is an excellent source for the isolation of novel actinobacterial diversity that produces novel metabolites. Particularly, the coastal regions of Tamil Nadu and Kerala are reported to be the target site by several authors for its diverse microbial population and rich metabolic profile. Through this study, we confirm that the coastal marine sediment contains abundant morphologically distinct actinobacterial populations, and notably, Streptomyces is predominant. The sediments from mangrove forests with rich organic content yielded high number of antagonistic actinobacteria than any other samples. The antimicrobial compound production efficacy of the isolated strains of actinobacteria was remarkable against various bacterial pathogens. The statistical analysis revealed that the four strains BDK01, BPY03, BRS07, and BMT01, which are identified as Streptomyces genus, were highly competitive compared to all other isolates investigated. In addition, the results throw light on the importance of several techniques to harness actinobacterial diversity from such regions for comprehensive understanding and exploring the application potential.

\section{ACKNOWLEDGMENT}

All authors thank CAS Marine Biology, Annamalai University, Parangipettai, for providing facilities to collect the samples from the deep marine. Furthermore, our sincere thanks to the Management of Sri Krishna Arts and Science College, Coimbatore, for providing entire lab requirements for the successful completion of work.

\section{AUTHORS' CONTRIBUTIONS}

Dr. Manikandan Madheslu - Data collection, Data analysis, and interpretation. Ms. Swapna Mani - Drafting the article. Mr. Duraimurugan Kasiviswanathan - Marine sediment samples collection. Dr. Solai Ramatchandirane Prabagaran - Design of the work, Supervision of the work, and Final approval of the version to be published.

\section{CONFLICTS OF INTEREST}

All authors have no conflicts of interest.

\section{REFERENCES}

1. Lam KS. Discovery of novel metabolites from marine actinomycetes. Curr Opin Microbiol 2006;9:245-51.

2. Keller M, Zengler K. Tapping into microbial diversity. Nat Rev Microbiol 2004;2:141-50.

3. Jensen PR, Mincer TJ, Williams PG, Fenical W. Marine actinomycete diversity and natural product discovery. Antonie Van Leeuwenhoek 2005;87:43-8

4. Bull AT, Ward AC, Goodfellow M. Search and discovery strategies for biotechnology: The paradigm shift. Microbiol Mol Biol Rev 2000;64:573-606.

5. Saha M, Jaisankar P, Das S, Sarkar KK, Roy S, Besra SE, et al. Production and purification of a bioactive substance inhibiting multiple drug resistant bacteria and human leukemia cells from a salt-tolerant marine actinobacterium sp. Isolated from the bay of bengal. Biotechnol Lett 2006;28:1083-8.

6. Sana B, Ghosh D, Saha M, Mukherjee J. Purification and characterization of a salt, solvent, detergent and bleach tolerant protease from a new gamma-proteobacterium isolated from the marine environment of the Sundarbans. Process Biochem 2006;41:208-15. 
7. Ramesh S, Mathivanan N. Screening of marine actinomycetes isolated from the Bay of Bengal, India for antimicrobial activity and industrial enzymes. World J Microbiol Biotechnol 2009;25:2103-11.

8. Vijayakumar R, Panneerselvam K, Muthukumar C, Thajuddin N, Panneerselvam A, Saravanamuthu R, et al. Optimization of antimicrobial production by a marine actinomycete Streptomyces afghaniensis VPTS31 isolated from Palk Strait, East Coast of India. Indian J Microbiol 2012;52:230-9

9. Basak P, Majumder NS, Nag S, Bhattacharyya A, Roy D, Chakraborty A, et al. Spatiotemporal analysis of bacterial diversity in sediments of sundarbans using parallel 16S rRNA gene tag sequencing. Microb Ecol 2015;69:500-11.

10. Godson PS, Chandrasekar N, Kumar SK, Vimi PV. Microbial diversity in coastal sediments during pre- and post-tsunami periods in the south east coast of India. Front Biol (Beijing) 2014;9:161-7.

11. Takizawa M, Colwell RR, Hill RT. Isolation and diversity of actinomycetes in the chesapeake bay. Appl Environ Microbiol 1993;59:997-1002.

12. Baltz RH, Demain AL, Davies JE. Manual of Industrial Microbiology and Biotechnology. U.S.: American Society for Microbiology Press; 2010 .

13. Jones A, Goodfellow M. Bergey's manual of systematic bacteriology. Microb Ecol 2012;5:437-64.

14. Green MR, Sambrook J. Molecular Cloning: A Laboratory Manual. $4^{\text {th }}$ ed. New York: Cold Spring Harb Lab Press; 2012. p. 2028. Available from: http://www.amazon.com/Molecular-Cloning-Laboratory-EditionThree/dp/1936113422. [Last accessed on 2012 Jun 15].

15. Shirling EB, Gottlieb D. Methods for characterization of Streptomyces species. Int J Syst Bacteriol 1966;16:313-40.

16. Goodfellow M, Kampfer P, Busse HJ, Trujillo ME, Suzuki K, Ludwig W, et al. Bergey's Manual of Systematic Bacteriology. Vol. 5. New York: Springer-Verlag; 2012.

17. Eccleston GP, Brooks PR, Kurtböke DI. The occurrence of bioactive micromonosporae in aquatic habitats of the sunshine coast in Australia. Mar Drugs 2008;6:243-61.

18. Parthasarathi S, Sathya S, Bupesh G, Samy R, Mohan M, Kumar G, et al. Isolation and Characterization of antimicrobial compound from marine Streptomyces hygroscopicus BDUS 49. World J Fish Mar Sci 2012;4:5-7.

19. Suput J, Lechevalier MP, Lechevalier HA. Chemical composition of variants of aerobic actinomycetes. Appl Microbiol 1967;15:1356-61

20. Becker B, Lechevalier MP, Gordon RE, Lechevalier HA. Rapid differentiation between nocardia and Streptomyces by paper chromatography of whole-cell hydrolysates. Appl Microbiol 1964;12:421-3.

21. McKerrow J, Vagg S, McKinney T, Seviour EM, Maszenan AM, Brooks $\mathrm{P}$, et al. A simple HPLC method for analysing diaminopimelic acid diastereomers in cell walls of gram-positive bacteria. Lett Appl Microbiol 2000;30:178-82.

22. Sasser M. Identification of bacteria by gas chromatography of cellular fatty acids. Tech Note 2001;101:1-6.

23. Levy SB. Active efflux, a common mechanism for biocide and antibiotic resistance. J Appl Microbiol 2002;92:65S-71.

24. Campfield B, Chen K, Kolls JK. Vaccine approaches for multidrug resistant gram negative infections. Curr Opin Immunol 2014;28:84-9.

25. Magarvey NA, Keller JM, Bernan V, Dworkin M, Sherman DH. Isolation and characterization of novel marine-derived actinomycete taxa rich in bioactive metabolites. Appl Environ Microbiol 2004;70:7520-9.

26. Mitra A, Santra SC, Mukherjee J. Distribution of actinomycetes, their antagonistic behaviour and the physico-chemical characteristics of the world's largest tidal mangrove forest. Appl Microbiol Biotechnol 2008;80:685-95.

27. Mahalakshm M, Srinivasan M, Murugan M, Balakrishn S, Devanathan K. Isolation and identification of total heterotrophic bacteria and human pathogens in water and sediment from cuddalore fishing harbour after the tsunami. Asian J Biol Sci 2011;4:148-56.

28. Das A, Bhattacharya S, Mohammed AYH, Rajan SS. In vitro antimicrobial activity and characterization of mangrove isolates of streptomycetes effective against bacteria and fungi of nosocomial origin. Brazil Arch Biol Technol 2014;57:349-56.

29. Ramesh S, Jayaprakashvel M, Mathivanan N. Microbial status in seawater and coastal sediments during pre- and post-tsunami periods in the Bay of Bengal, India. Mar Ecol 2006;27:198-203.

30. Levinton JS, Levinton JS. Marine Biology: Function, Biodiversity, Ecology. Vol. 420. New York: Oxford University Press; 1995.

31. Vijayakumar R, Muthukumar C, Thajuddin N, Panneerselvam A, Saravanamuthu R. Studies on the diversity of actinomycetes in the
Palk Strait region of Bay of Bengal, India. Actinomycetologica 2007;21:59-65.

32. Tiago I, Chung AP, Veríssimo A. Bacterial diversity in a nonsaline alkaline environment: Heterotrophic aerobic populations. Appl Environ Microbiol 2004;70:7378-87.

33. Tamaki H, Sekiguchi Y, Hanada S, Nakamura K, Nomura N, Matsumura $\mathrm{M}$, et al. Comparative analysis of bacterial diversity in freshwater sediment of a shallow eutrophic lake by molecular and improved cultivation-based techniques. Appl Environ Microbiol 2005;71:2162-9.

34. Suthindhiran K, Kannabiran K. Diversity and exploration of bioactive marine actinomycetes in the Bay of Bengal of the Puducherry coast of India. Indian J Microbiol 2010;50:76-82.

35. Remya M, Vijayakumar R. Isolation and characterization of marine antagonistic actinomycetes from West Coast of India. Med Biol 2008; $15: 13-9$

36. Fourati-Ben Fguira L, Fotso S, Ben Ameur-Mehdi R, Mellouli L, Laatsch H. Purification and structure elucidation of antifungal and antibacterial activities of newly isolated Streptomyces Sp. Strain US80. Res Microbiol 2005;156:341-7.

37. Guo Y, Zheng W, Rong X, Huang Y. A multilocus phylogeny of the streptomyces griseus 16S rRNA gene clade: Use of multilocus sequence analysis for streptomycete systematics. Int J Syst Evol Microbiol 2008;58:149-59.

38. He H, Liu C, Zhao J, Li W, Pan T, Yang L, et al. Streptomyces zhaozhouensis $\mathrm{sp}$. Nov. an actinomycete isolated from candelabra aloe (Aloe arborescens mill). Int J Syst Evol Microbiol 2014;64:1096-101.

39. Jensen PR, Dwight R, Fenical W. Distribution of actinomycetes in near-shore tropical marine sediments. Appl Environ Microbiol 1991;57:1102-8.

40. Sujatha P, Bapi Raju KV, Ramana T. Studies on a new marine streptomycete BT-408 producing polyketide antibiotic SBR-22 effective against Methicillin resistant Staphylococcus aureus. Microbiol Res 2005;160:119-26.

41. Goodfellow M. Genus Nocardia trevisan 1889, $9^{\wedge}<$ AL. Bergey's Man Syst Bacteriol 1989;4:2350-61.

42. Goodfellow M, Maldonado LA. The families Dietziaceae, Gordoniaceae, Nocardiaceae and Tsukamurellaceae. The Prokaryotes. New York: Springer; 2006. p. 843-88.

43. El-Shatoury SA, El-Shenawy NS, Abd El-Salam IM. Antimicrobial, antitumor and in vivo cytotoxicity of actinomycetes inhabiting marine shellfish. World J Microbiol Biotechnol 2009;25:1547-55.

44. Kathiresan K. A review of studies on Pichavaram Mangrove, Southeast India. Hydrobiologia 2000;430:185-205.

45. Nithyanand P, Manju S, Karutha Pandian S. Phylogenetic characterization of culturable actinomycetes associated with the mucus of the coral Acropora digitifera from gulf of mannar. FEMS Microbiol Lett 2011;314:112-8.

46. Miyadoh S. Research on antibiotic screening in Japan over the last decade: A producing microorganism approach. Actinomycetologica 1993; 7:100-6.

47. Berdy J. Are actinomycetes exhausted as source of secondary metabolites? Proc Int Symp Biol Actinomycetes 1995;19:13-34.

48. Wu J, Zhang Q, Deng W, Qian J, Zhang S, Liu W, et al. Toward improvement of erythromycin A production in an industrial Saccharopolyspora erythraea strain via facilitation of genetic manipulation with an artificial attB site for specific recombination. Appl Environ Microbiol 2011;77:7508-16.

49. Carlson S, Marler L, Nam SJ, Santarsiero BD, Pezzuto JM, Murphy BT, et al. Potential chemopreventive activity of a new macrolide antibiotic from a marine-derived Micromonospora Sp. Mar Drugs 2013;11:1152-61.

50. Mukai A, Fukai T, Matsumoto Y, Ishikawa J, Hoshino Y, Yazawa K, et al. Transvalencin $\mathrm{Z}$, a new antimicrobial compound with salicylic acid residue from Nocardia transvalensis IFM 10065. J Antibiot (Tokyo) 2006;59:366-9.

51. Tsuda M, Yamakawa M, Oka S, Tanaka Y, Hoshino Y, Mikami Y, et al. A cytotoxic compound from actinomycete Nocardia brasiliensis. J Nat Prod 2005;68:462-4.

52. Gill KA, Berrué F, Arens JC, Kerr RG. Isolation and structure elucidation of cystargamide, a lipopeptide from Kitasatospora cystarginea. J Nat Prod 2014;77:1372-6.

53. Phongsopitanun W, Thawai C, Suwanborirux K, Kudo T, Ohkuma M, Tanasupawat S, et al. Streptomyces chumphonensis $\mathrm{Sp}$. Nov. isolated from marine sediments. Int J Syst Evol Microbiol 2014;64:2605-10.

54. Bérdy J. Bioactive microbial metabolites. J Antibiot (Tokyo) 2005;58:1-26. 
55. Kurtböke DI. Biodiscovery from rare actinomycetes: An ecotaxonomical perspective. Appl Microbiol Biotechnol 2012;93:1843-52.

56. Bull AT, Stach JE., Ward AC, Goodfellow M. Marine actinobacteria: Perspectives, challenges, future directions. Antonie Van Leeuwenhoek 2005;87:65-79.

57. Braña AF, Fiedler HP, Nava H, González V, Sarmiento-Vizcaíno A, Molina A, et al. Two Streptomyces Species producing antibiotic, antitumor, and anti-inflammatory compounds are widespread among intertidal macroalgae and deep-sea coral reef invertebrates from the central Cantabrian Sea. Microb Ecol 2015;69:512-24.

58. Sathya R, Ushadevi T. Industrially important enzymes producing Streptomyces Species from mangrove sediments. Int J Pharm Pharm Sci 2014;6:233-7.

59. Lakshmi G, Raja A, James RA. Study on antimycobacterial activity of marine actinomycetes from coromondal coastal region of Southern India. Int J Pharm Pharm Sci 2014;6:144-7. 